\title{
Evaluation of the efficiency of the vertical acoustic shield to protect the environment from noise
}

\author{
Elizaveta Lugovaya ${ }^{1}$, Dmitrii Garnizonov ${ }^{1}$, Tatiana Kaverzneva ${ }^{1 *}$ and Shemiakina Tatiana ${ }^{1}$ \\ ${ }^{1}$ Peter the Great St.Petersburg Polytechnic University, 195251 St. Petersburg, Russia
}

\begin{abstract}
This study analyzes the noise protection properties of the vertical acoustic shield in order to obtain comparative data on its efficiency. This is essential for reduction of the negative impact of traffic noise on the population, the environment and economic facilities, including energy facilities.
\end{abstract}

\section{Introduction}

In modern large cities, noise is a common environmental pollution, which negatively affects human health. Noise exposure causes irritation, absent-mindedness, affects the emotional and mental state of a person. Prolonged acoustic exposure can result in irreversible changes in the human body. Also, the impact of noise negatively affects the personnel, which in its turn cannot but affect the functioning of energy facilities.

The negative impact of noise is a problem of a global nature. This is confirmed by the data presented in the report of the European Green Commission [1]: more than 20\% of the EU population lives in areas with noise levels above $65 \mathrm{dBA}$, about $40 \%$ - from 55 to 65 $\mathrm{dBA}$. These values exceed the permissible limits [2], therefore, at present, noise protection of residential areas, which occupy $50-60 \%$ of the city's territory, constitutes a pressing issue.

Traffic flows are one of the main sources of noise in cities. Traffic noise accounts for up to $80 \%$ of all city noise entering residential premises and other places of human activity [3]. Transportation systems play a critical role in meeting people's mobility and accessibility needs, so it is not possible to exclude traffic from our lives. This means that it is vital to develop and adopt organizational and administrative, architectural and planning, construction and acoustic and other measures to reduce the noise level produced by vehicles and to mitigate its impact on public health [4].

There exist various measures to protect residential areas from increased noise load [5]. They consist of a set of solutions allowing to ensure a comfortable stay of people in these areas. They include installation of sound-absorbing and noise-reflecting acoustic shields, construction of hollow roads, green spaces, traffic management [6,7]. With the right approach to the development of such measures, the acoustic safety of the area can be achieved.

* Corresponding author: kaverztt@mail.ru 
A relatively inexpensive, but at the same time one of the effective means of protection against traffic noise is an acoustic shield. The installation of well-designed shields can either completely eliminate the problem of excess noise, or significantly facilitate the solution of this problem. Also, the installation of noise protection shields allows to use the areas, which without such a shield otherwise would be unsuitable due to exceeding the noise standards, for the construction of residential buildings.

Currently, most scientists consider the installation of acoustic shields as the most effective measure against traffic noise [8-10]. But the shield will be effective only if all the features of the area where it is to be located are taken into account in the process of its development. It is necessary to develop the correct combination of materials and determine the size of the shield with due regard to the peculiarities of the area. In view of the foregoing, it is advisable to analyze the noise protection properties of the most commonly used type of shield, the vertical shield, when changing various parameters. Knowledge about the efficiency of the shield will help to simplify and speed up the development process and improve the noise protection of the selected area.

\section{Methods and materials}

In this study, the key role is dedicated to the problem of determining the efficiency of the vertical noise shield when changing the specified conditions.

In order to gain insight into the problem and study it in detail, it is necessary to apply a number of scientific research methods, with the help of which it seems possible to achieve the set goal.

In the process of work the following activities were carried out: analysis of literature, calculation of efficiency, comparative analysis of the results.

On the basis of the comparative analysis, the corresponding conclusions about the efficiency were made.

\section{Results}

There exist a lot of methods for determining the efficiency of a shield. Having studied the research materials devoted to the issue of determining a more accurate method, the Maekawa method was chosen for the calculations, the inaccuracy of which does not exceed $3 \mathrm{~dB}$ [4, $11,12,13,14]$.

The shield efficiency $\Delta \mathrm{L}_{\text {scr }}$ is calculated by the Maekawa formula (1) using the Fresnel number:

$$
\Delta \mathrm{L}_{\mathrm{sh}}=20 \log \frac{\sqrt{2 \pi|\mathrm{N}|}}{\mathrm{th} \sqrt{2 \pi|\mathrm{N}|}}+5
$$

where $\mathrm{N}=2 \delta / \lambda$ - the Fresnel number;

$\delta=\mathrm{a}+\mathrm{b}-\mathrm{c}-$ the path-length difference of sound beams (Fig. 1);

$\mathrm{a}=\sqrt{1^{2}+\left(\mathrm{H}_{\mathrm{sh}}-\mathrm{H}_{\mathrm{ns}}\right)^{2}}$ - the shortest distance between the acoustic center of the noise source - $\mathrm{a}$ car, in our case, and the top edge of the shield;

$b=\sqrt{m^{2}+\left(H_{s h}-H_{n s}\right)^{2}}$ - the shortest distance between the reference point and the top edge of the shield;

$\mathrm{c}=\sqrt{(1+\mathrm{m})^{2}+\left(\mathrm{H}_{\mathrm{sh}}-\mathrm{H}_{\mathrm{ns}}\right)^{2}}$ - the shortest distance between the acoustic center of the noise source and the reference point; 
$\mathrm{H}_{\mathrm{rp}}=1,5 \mathrm{~m}, \mathrm{H}_{\mathrm{sh}}=1 \mathrm{~m}, \mathrm{~m}=20 \mathrm{~m}-$ will not change when calculating the efficiency value $\Delta$ Lscr, $\mathrm{dB}$ at the reference point depending on the height of the shield and the distance to the noise source (Table 1);

$\mathrm{H}_{\mathrm{rp}}=1,5 \mathrm{~m}, \mathrm{H}_{\mathrm{sh}}=1 \mathrm{~m}, \mathrm{l}=5 \mathrm{~m}$ - will not change when calculating the efficiency value $\Delta$ Lscr, $\mathrm{dB}$ at the reference point, depending on its distance (Table 2).

$\lambda=\mathrm{c} / \mathrm{f}=331 / 500=0,662 \mathrm{~m}-$ wavelength [15].

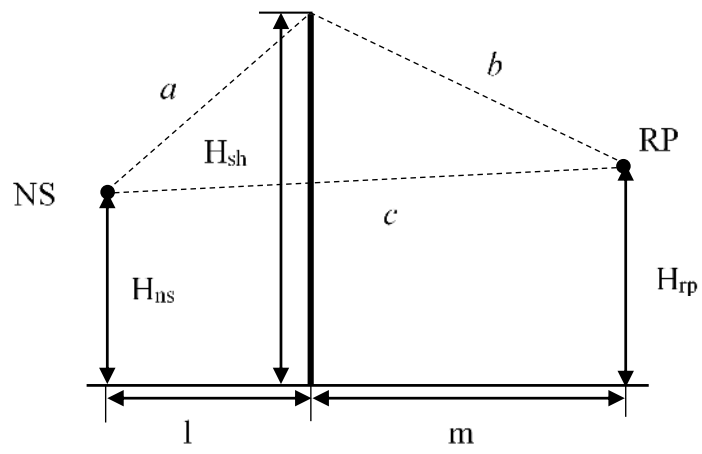

Fig. 1. Schematic representation of the location of NS, AS, RP.

The calculation results are presented in the tables (Table 1, Table 2):

Table 1. The efficiency values of the vertical acoustic shield at the reference point depending on the height of the shield and the distance to the noise source.

\begin{tabular}{|c|c|c|c|c|}
\hline \multirow{3}{*}{ Shield height $\mathrm{H}_{\text {scr }}, \mathrm{m}$} & \multicolumn{4}{|c|}{ Efficiency value $\Delta \mathrm{L}_{\mathrm{scr}}, \mathrm{dB}$} \\
\cline { 2 - 5 } & \multicolumn{4}{|c|}{ Distance from the shield to the noise source $1, \mathrm{~m}$} \\
\cline { 2 - 5 } & $\mathbf{5}$ & $\mathbf{8}$ & $\mathbf{1 0}$ & $\mathbf{1 5}$ \\
\hline $\mathbf{2}$ & 8,9 & 7,8 & 7,3 & 6,7 \\
\hline $\mathbf{2 , 5}$ & 11,6 & 10,1 & 9,4 & 8,5 \\
\hline $\mathbf{3}$ & 13,8 & 12,2 & 11,4 & 10,3 \\
\hline $\mathbf{4}$ & 17,1 & 15,5 & 14,7 & 13,5 \\
\hline
\end{tabular}

1. The higher the shield is, the more efficiency it has at any distance from the noise source.

2. The shield efficiency decreases with a greater distance from the noise source.

3. The acoustic shield should be positioned as close as possible to the noise source.

Table 2. The efficiency values of the vertical acoustic shield at the reference point depending on the height of the shield and the distance to the reference point.

\begin{tabular}{|c|c|c|c|c|}
\hline \multirow{2}{*}{ Shield height $\mathrm{H}_{\mathrm{scr}}, \mathrm{m}$} & \multicolumn{4}{|c|}{ Efficiency value $\Delta \mathrm{L}_{\text {scr, }} \mathrm{dB}$} \\
\cline { 2 - 5 } & \multicolumn{4}{|c|}{ Distance from the shield to the reference point m, m } \\
\cline { 2 - 5 } & $\mathbf{1 0}$ & $\mathbf{2 0}$ & $\mathbf{3 0}$ & $\mathbf{4 0}$ \\
\hline $\mathbf{2}$ & 9 & 8,9 & 8,9 & 8,9 \\
\hline $\mathbf{2 , 5}$ & 11,8 & 11,6 & 11,5 & 11,5 \\
\hline $\mathbf{3}$ & 14,1 & 13,8 & 13,8 & 13,8 \\
\hline $\mathbf{4}$ & 17,5 & 17,1 & 17,1 & 17 \\
\hline
\end{tabular}

The obtained results show that the efficiency of the shield decreases when the reference point is moved away and does not change when a certain distance is reached. This distance is the one at which residential buildings can start to be located. 


\section{Discussions and conclusions}

Reducing noise from vehicles near residential buildings is an important task and the obtained results can assist in solving it.

With the help of various methods of scientific research the following has been established:

1. Dependence of the vertical acoustic shield efficiency at the reference point on the height of the shield and the distance to the noise source.

2. Dependence of the vertical acoustic shield efficiency at the reference point on the height of the shield and the distance to the reference point.

Similar calculations can be made for any specified parameters, thereby determining other characteristics, for example, the zone of greatest noise, the required shield height, etc.

The practical value of the research results lies in the possibility of their application into practice and for further improvement of acoustic shields.

\section{References}

1. Future noise policy European commission Green Paper, "Noise/NEWS International", vol.5, Number 2, June, pp 77-98 (1997)

2. SN 2.2.4/2.1.8.562-96 Shum na rabochikh mestakh, v pomeshheniyakh zhily $k h$, obshhestvenny kh zdanij i na territorii zhiloj zastrojki, Postanovleniem Goskomsane pidnadzora RF № 36, 31 oktyabrya (1996)

3. H.M. Elmehdi, Road traffic noise in major uae cities: Levels and projects' health effects Traffic Noise: Exposure, Health Effects and Mitigation, pp 59-76 (2017)

4. I.L. Shubin, Akusticheskij raschet i proektirovanie konstrukczij shumozashhitny `kh e kranov, Dis. dok. tekh. nauk., Moskva, str 19 (2011)

5. T.T. Kaverzneva, I.L. Skripnik, S.V. Voronin, Voprosy`oczenki i izmereniya shuma $v$ gorodskikh usloviyakh, Sovremenny 'e tekhnologii i sistemy`: upravlenie, e konomika, transport, parvo, S 245-248 (2019)

6. Yu.A. Vinnikov, Razrabotka shumozashhitny 'kh metodov s primeneniem zeleny 'kh nasazhdenij pri razvitii selitebny $k$ h territorij gorodskoj zastrojki, Dis. kon. tekh. nauk., Moskva (2010)

7. Yu.S. Borodkina, T.T. Kaverzneva, Shumovaya nagruzka mnogoe 'tazhny `kh zdanij $i$ raschet ikh zashhishhennosti ot transportnogo shuma, Materialy` nauchnoj konferenczii s mezhdunarodny`m uchastiem, S 6-9 (2018)

8. V.A. Vasil'ev, V.K. Ksenofontova, Shum avtomobil'nogo transporta, Noise theory and practice I, str. 66-76 (2019)

9. N.V. Tyurina, Akusticheskie e 'krany`kak universal 'noe sredstvo e kologicheskoj bezopasnosti avtomobil `ny $k h$ dorog, Sbornik trudov II Vserossijskij nauchnoprakticheskij seminar s mezhdunarodny`m uchastiem "E`kologizacziya avtomobil nogo transporta: peredovoj opy`t Rossii i stran Evropejskogo Soyuza", SPb, $7-9$ aprelya, S. 112-118 (2004)

10. V.V. Shtabinskij, Issledovanie zvukopogloshhayushhikh svojstv materialov $i$ zvukoizoliruyushhej sposobnosti konstrukczij shumozashhitny 'kh e kranov, «Stroitel `naya fizika v XXI veke», Materialy` nauchno-tekhnicheskoj konferenczii. NIISF RAASN, str. 282-286 (2006)

11. C. Guarnaccia, J. Quartieri, N. E. Mastorakis, Analysis of methods to evaluate the noise reduction due to acoustic barriers installation, International Journal of Mechanics, 8(1), 258-266 (2014) 
12. G.M. Kurczev, E.A. Bezverkhaya, Raschet e `ffektivnosti shumozashhitny `kh e `kranov dlya maloe 'tazhny $k$ h zhily ' $k$ h zastroek, udalenny $k h$ ot avtodorog do $200 \mathrm{~m}$, NOISE THEORY AND PRACTICE I, str. 64-71 (2019)

13. T. Kaverzneva, D. Tarkhov, A. Uljanov, V. Senchenko, C. Pshenichnaya, I. Alibekova, Criteria for ensuring acoustic safety in the assembly shops of machine-building enterprises, Paper presented at the IOP Conference Series: Materials Science and Engineering, 643(1), doi:10.1088/1757-899X/643/1/012119 (2019)

14. N. Rumyantseva, E. Primak, A. Uljanov, V. Kiss, Assessment of an occupational risk using injury safety indicators, Paper presented at the IOP Conference Series: Materials Science and Engineering, 666(1), doi:10.1088/1757-899X/666/1/012090 (2019)

15. GOST 31295.2-2005 Shum. Zatukhanie zvuka pri rasprostranenii na mestnosti. Chast 2. Obshhij metod rascheta. M.: Standartinform (2006) 